\title{
Examining safe yield and sustainable yield for groundwater supplies and moving to managed yield as water resource limits become a reality
}

\author{
S. J. Meyland \\ Department of Environmental Technology, \\ New York Institute of Technology, USA
}

\begin{abstract}
When determining how much water can safely be withdrawn from an aquifer system, the concept of "safe yield" has been used. This term has come to mean if annual withdrawals do not exceed the annual rate of recharge, then the withdrawals are within a safe level of extraction. However, this approach has been shown to be an oversimplification of aquifer dynamics. It is flawed for it fails to incorporate other processes occurring in an aquifer as water is pumped from the system. A new approach is suggested that adds a safety margin to the assessment of the production capacity of an aquifer. This approach is defined as "managed yield" and it is recommended as a replacement for safe yield when developing management strategies for groundwater systems.

Keywords: groundwater flow, groundwater, groundwater management, groundwater depletion, safe yield, sustainable yield, managed yield, water budget, water supply, water sustainability.
\end{abstract}

\section{Introduction}

National Geographic Magazine's special issue on water described the world's present water situation as follows:

"Nearly 70 percent of the World's freshwater is locked in ice. Most of the rest is in aquifers that we're draining much more quickly than the natural recharge rate. Two-thirds of our water is used to grow food. With 83 million more people on the earth each year, water demand will keep going up unless we change how we use it" [1]. 
While the basic statistics of water distribution are well-known, it is still unsettling to see the documentation of groundwater depletion continue to accumulate, telling the story of the on-going loss of this resource. Marc Bierkens and his team $[2,3]$ found that groundwater around the world is being pumped faster than it can be replenished, at rates that have doubled since the 1960s. Much of this increase is due to increased agricultural use of groundwater which accounts for $70-80 \%$ of the increase, globally. Bierkens modeled water flow across the landscape to estimate the fate of this water via infiltration, evaporation, and runoff for land parcels around the globe. They then calculated how much water was leaving and entering the world aquifers. One interesting consequence of this increased use is that a majority of this pumped groundwater, as much as $95 \%$, ends up in the oceans where it is a contributor to the world's sea level rise. The research team found that groundwater use has contributed $25 \%$ of the sea level rise observed since 2000 .

Many of the world's largest aquifers are implicated in the depletion of groundwater supplies. The Great Artesian Basin in Australia is the largest aquifer system in the world. It is an essential water source for Queensland and South Australia that is disappearing [4]. Other major aquifers being impacted include the Guarani Aquifer, shared by Brazil, Argentina, Paraguay and Uruguay and the Ogallala Aquifer of the central US. Other hotspots identified in the Bierkens study [3] on groundwater depletion were: northeastern China, northwestern India, Iran, northeastern Pakistan, southeastern Spain, California's Central Valley and Yemen. Ironically, the Queensland area of Australia was hit by catastrophic floods in early January 2011. Although the flood waters ended the drought, it will take "years of significant rain to bring aquifers up to healthy levels" according to Chris Cocklin, an environmental scientist at the University of Queensland [5].

While it is possible to take a global snap shot of aquifer depletion as Bierkens did, the impact on smaller, local aquifers needs a different approach. The U.S. Geological Survey (USGS) is the premier investigator of groundwater conditions across the nation. A USGS Fact Sheet on groundwater depletion, prepared by Bartolino and Cunningham [6], reports that groundwater provides approximately $50 \%$ of the nation's drinking water, serving 140 million people. Nearly $100 \%$ of the water used by rural populations is groundwater and over 50 billion gallons per day of groundwater is used to support the nation's agricultural activities. Bartolino and Cunningham [6] found that many areas of the United States are experiencing groundwater depletion and that the volume of groundwater in storage is decreasing in response to pumping in many areas of the United States.

\section{A groundwater management program is needed at the local and national level}

An essential tool in water management and allocation is the tabulation of the total water resource. This tabulation, known as a water budget, is an accounting of inflows, outflows and water in storage in an aquifer or in a surface water system. While a predevelopment water budget is an interesting exercise, 
Alley et al. [7] believe that the more helpful tabulation is a current or postdevelopment water budget that includes the influence of human activities. The predevelopment water budget characterizes the groundwater resource prior to human development. Its use has led to the creation of what has come to be known as the "safe yield myth." Alley et al. [7-12] have written in detail regarding the flaws of the safe yield concept and its transition into what they call the safe yield myth.

Alley explains that safe yield "is a myth because it is an oversimplification of the information that is needed to understand the effect of developing a groundwater system... As human activities change the system, the components of the water budget (inflows, outflows, and changes in storage) also will change and must be accounted for in any management decision" [7]. Before the issues of sustainable yield or managed yield are discussed, it is useful to briefly examine the role of the water budget for an aquifer system and the safe yield myth.

\section{Water budgets and the myth of safe yield}

The traditional concept of a water supply "safe yield" was derived from surface water reservoir studies. The safe yield of a reservoir of known size and capacity, according to Alley and Leake, defined the "maximum quantity of water that could be supplied from the reservoir during a critical period" such as a drought [13]. The term safe yield was first used in 1915 to mean the "quantity of water that can be pumped regularly and permanently without dangerous depletion of the storage reserve" [14]. Todd was one of many who later extended the definition of safe yield to groundwater, defining it as the "amount of water which can be withdrawn from it annually without producing an undersired result" [15]. According to Sophocleous [11] other researchers who contributed to the evolution of the term included Meinzer (1920), Condling (1946), and Banks (1953). Banks offered an increasingly expanded view of safe yield that included hyrologic, economic, quality and legal considerations.

Aquifer yield can be viewed from many different scales such as for a well, for a specific aquifer or for an entire aquifer basin or system. Basin yield can be defined as the "maximum rate of withdrawal that can be sustained by the complete hydrogeologic system in a basin without causing unacceptable declines in hydraulic head anywhere in the system or causing unaccptable changes to any other componets of the hydroloic cycle in the basin" $[11,16]$.

While these generalized definitions seem reasonable, the concept of safe yield has been popularized into a shorthand version that defines the safe yield of a groundwater basin as the long-term balance between "the amount of ground water withdrawn annually and the annual amount of recharge" $[12,13]$.

The misunderstanding of safe yield for groundwater supplies is related to the traditional water budget formula that expresses the relationship between inflow, outflow and water in storage for an aquifer.

$$
\text { Inflow }=\text { Outflow } \pm \Delta \text { Storage }
$$


This simple relationship describes a natural aquifer system that is not influenced by human activities, e.g., an aquifer in a steady state of dynamic equilibrium. It represents a finite amount of water in the system. In a natural, undeveloped system, the quantity and flow of water in an aquifer is in balance. Natural variations are off-set by minimal changes in storage according to seasonal variability. In the undeveloped aquifer system, the inflow component is mainly represented by precipitation/recharge. The outflow component is composed of discharge into boundary waters such as the ocean, lakes, and other boundary features. It may also include discharge into surface waters such as streams and rivers that run through an aquifer watershed.

\section{Pumping upsets the natural balance of flow in an aquifer}

Significant changes to the water held in storage come into play when the equilibrium between inflow and outflow is upset. Apart from normal variations, the greatest factor that draws water from storage is when human development of an aquifer tips the equilibrium balance. Then, outflow (total water lost from the system) may begin to exceed inflow (Outflow $>$ Inflow). To meet the new extraction of water due to pumping, water must come from storage ( $\Delta$ Storage). However, normal outflow discharges will still continue. If water development and withdrawals increase, total water leaving the system may become progressively greater than inflow. The extra outflow represented by pumpage is water removed from storage.

Eventually, if pumping stabilizes, normal outflow will decline as the imbalance between inflow and total water loss continues, until a new equilibrium is reached. Recharge of the aquifer may also increase, often in the form of induced recharge from surface water bodies such as streams and ponds, to replace the water being loss from storage. Thus, there is an important relationship that exists between the aquifer equilibrium and surface water features within an aquifer watershed. According to Sophocleous, "the sustainable yield of an aquifer must be considerably less than recharge if adequate amounts of water are to be available to sustain both the quantity and quality of streams, springs, wetlands, and groundwater-dependent ecosystems" [12].

The safe yield myth involves several misunderstandings. First, safe yield is used to evaluate water withdrawals for human needs. The unspoken presumption is human needs are paramount to all other users or components represented in the system. Once the human needs are met, then the assessment examines the water remaining in the system. Or, the normal loss of water from the aquifer as outflow may be forgotten or ignored entirely.

Second, the safe yield approach equates the aquifer to a large storage container. The myth of safe yield implies that if human withdrawals do not exceed recharge, then the amount of water left behind is static, like water held in a massive, leak-proof tank.

In reality, an aquifer is a leaky container. Water is always leaving the system through outflow. When large withdrawals from the aquifer continue to drain water from storage, the aquifer system as a whole shrinks because the total 
volume of water is less than before. Changes occur within the aquifer system such as the water table drops, the discharge boundaries may change, and features that once were fed by groundwater (streams, ponds, or wetlands) may disappear or be diminished. Where an aquifer is surrounded by saltwater, as the freshwater storage declines, saltwater invades the margins of the aquifer in a process known as saltwater intrusion.

In the case of saltwater intrusion, the safe yield concept also illustrates a companion belief that views water outflow from the system as "wasted" water. Many water utility operators, for example, portray water they fail to capture as "lost" water. However, water outflow that meets the ocean establishes another equilibrium boundary, the saltwater/freshwater interface. When the total freshwater volume declines, the saltwater/freshwater interface can be destabilized.

\section{Moving toward sustainable yield and beyond}

In recognition of the pitfalls posed by using the traditional safe yield approach for groundwater management, a newer term is coming into the literature, that of sustainable yield. According to the American Society of Civil Engineers' Committee on Sustainability Criteria, "sustainable water resource systems are those designed and managed to fully contribute to the objectives of society, now and in the future, while maintaining their ecological, environmental and hydrological integrity" [17].

The U.S. Geolgoical Survey has developed an even broader definition, while still using the term safe yield:

"The amount of ground water that can be safely withdrawn from a groundwater basin annually, without producing an undesirable result. Undesirable results include but are not limited to depletion of groundwater storage, the intrusion of water of undesirable quality, the contravention of existing water rights, the deterioration of the economic advantages of pumping (such as the excessively lowered water levels and the attendant increased pumping lifts and associated energy costs), excessive depletion of streamflow by induced infiltration, and land subsidence" [7].

To formalize the move away from safe yield to a more holistic understanding of pumping impacts on an aquifer system, Mandel and Shiftan [18] developed a six-step process for determining how much water an aquifer system can sustainably produce. The steps are:

1. Determine average annual replenishment.

2. Identify the most stringent constraint, i.e., the first unacceptable effect that will occur when water levels are lowered.

3. Find the quantitative relation between water-level elevations and the occurrence of this unacceptable effect. In many cases, it is possible to confine attention to certain key locations that are especially sensitive to water level changes. 
4. Define minimal water levels for the whole aquifer or for the above-mentioned key positions.

5. Compute the rate of natural outflow that will occur when a quasisteady state of flow commensurate with minimal water level [losses] is established.

6. The sustained yield is the difference between (2) and (5) [11].

While this step-by-step process is helpful in developing a more refined amount of water production from an aquifer system, there are still important caveats attached to the process. Sophocleous [11] points out these cautions. "Any change in conditions, such as changes in land use, economics, or importation of new water supplies, would require calculation of a new yield...Clearly, no unique and constant value can be attached to safe yield. In addition, the definitions of safe yield of an aquifer often fail to address the impacts of groundwater exploitation on related surface water and on areas outside the area of development...There is no valid generic rule, such as pumping the natural recharge, that will lead to a desirable economic or stable (non-depleting) level of groundwater development...The level of groundwater development should be calculated using specified withdrawal rates, well field locations, drawdown limits, and a defined planning horizon."

\section{The case of Long Island, New York}

The groundwater system beneath Long Island, New York provides $100 \%$ of the water needs for Nassau and Suffolk Counties. The aquifer system of Long Island is well-studied and the basic flow regimes and processes are generally understood. Nassau and Suffolk are the two eastern-most counties on the island of Long Island, while Kings (Brooklyn) and Queens Counties are the westernmost counties and are two of the five boroughs that make up New York City. While the aquifer system occurs beneath all four counties, Kings and Queens Counties receive their water supply from the surface water reservoir systems operated by New York City and have largely, but not totally, abandoned the use of the groundwater supply since around 1990 when the last major groundwater operations were discontinued.

\subsection{Nassau County, New York}

Nassau County is the smaller of the two counties referred to collectively as Long Island. It is approximately $287 \mathrm{sq}$. miles in area with a population of 1.3 million residents. Suffolk County, by comparison, is 912 sq. miles in area with a population of 1.5 million residents. Nassau County is known as the nation's first suburb due to the Levittown develops after World War Two. It has since matured into a stable and largely built-out community with only a small amount of remaining undeveloped, open space. Suffolk County is still in the development mode, with the greatest concentration of development along its western border with Nassau County. Toward the eastern end of Suffolk, 
significant open space remains and population densities are much lower than on the western end of the county. Agriculture is an important activity in eastern Suffolk County. Suffolk County has not yet reached the level of overpumping that Nassau County is experiencing.

Hydrologically, the aquifer system beneath Long Island is a series of sand and gravel formations, significantly influenced by glacial activities during the last ice age, 10,000 to 15,000 years ago. Three primary aquifers provide water for Long Islanders. The uppermost formation is the Upper Glacial aquifer. It is comprised of reworked glacial deposits, mainly sand and gravel. Next is the Magothy aquifer which is the largest formation. The deepest aquifer is the Lloyd aquifer which is a confined aquifer and is the smallest formation. It is separated from the Magothy by a confining layer, the Raritan Clay, which is between 50 and 200 feet thick. Beneath the Lloyd aquifer is bedrock, an aquiclude, which does not hold usable amounts of water.

\subsubsection{Nassau County conditions}

Because the two counties are at different stages of growth and development, their water conditions are also at different stages. Nassau has reached the limits of water production from its portion of the aquifer system and is past what would be considered sustainable yield. The consequences of its water withdrawal history are easily seen in the drop in the water table across the county over time and in the loss of stream flow for many streams which historically received at least $85 \%$ of total flow from groundwater [19].

Being an island surrounded by saline water, saltwater intrusion is a serious concern and both the north and south shores of Nassau County continue to experience saltwater intrusion problems that complicate water production operations in affected areas. This condition is partially related to the installation of sewers with coastal discharge. Ninety percent of the population is served by sewers. Sewer installation was in response rising level of nitrates and other pollutants detected in the drinking water supply and raw groundwater. After the sewers were constructed, a large portion of the water pumped from the aquifers was permanently lost (consumptively used) from the groundwater system. According to Maimone [20], the decision was made to "allow the streams to dry up in exchange for improved groundwater quality."

Over the years, Nassau County conducted periodic studies of the groundwater supply. These documented the progressive decline in the resource in terms of water quality and quantity. The last major study was conducted in 1998 [19].

Annual public water supply pumpage in Nassau County from 1970 to 2004 was between 170 and 200 million gallons per day (mgd) with the highest pumpage generally occurring in the most recent time periods [21]. Nassau County selected the value of $180 \mathrm{mgd}$ of consumptive use as the "safe yield" of the aquifer. The water balance analysis for the 1998 Ground Water Study relied on the traditional view of safe yield, balancing recharge with discharge.

From table 1, it is shown that pumpage is $180 \mathrm{mgd}$. Water production was equal to the safe yield value set by the county. Based on the values in table 1 , the County concluded that, "as long as recharge exceeds the amount of 
Table 1: $\quad$ Water budget for Nassau county, New York 1998* [18].

\begin{tabular}{|l|l|l|c|}
\hline $\begin{array}{l}\text { InFlow to the Aquifer } \\
\text { System } \\
\text { Gallons/Day }\end{array}$ & MGD & $\begin{array}{l}\text { Discharge from Aquifer } \\
\text { System in Million } \\
\text { Gallons/Day }\end{array}$ & MGD \\
\hline Recharge & 341 & $\begin{array}{l}\text { Pumpage from Glacial } \\
\text { Aquifer }\end{array}$ & 2 \\
\hline Inflow to Glacial Aquifer & 21 & $\begin{array}{l}\text { Pumpage from Magothy } \\
\text { Aquifer }\end{array}$ & 166 \\
\hline Inflow to Magothy Aquifer & 16 & $\begin{array}{l}\text { Pumpage from Lloyd } \\
\text { Aquifer }\end{array}$ & 12 \\
\hline Inflow to Lloyd Aquifer & 6 & Discharge to Streams & 35 \\
\hline & & $\begin{array}{l}\text { Outflow from Glacial to } \\
\text { coast }\end{array}$ & 90 \\
\hline & $\begin{array}{l}\text { Outflow from Magothy to } \\
\text { coast }\end{array}$ & 73 \\
\hline & $\begin{array}{l}\text { Outflow from Lloyd to } \\
\text { coast }\end{array}$ & 6 \\
\hline TOTAL INFLOW & 384 & TOTAL OUTFLOW & 384 \\
\hline
\end{tabular}

*Note: a fully documented water budget would include values for water in storage.

groundwater withdrawn for water supply, the quantity of groundwater available in the aquifers for public supply will be more than adequate" [19]. Not long after the 1998 Study, Nassau County chose to raise its "safe yield" level to 185 mgd, based on the assumption that the recharge basin system was collecting and recharging more precipitation than earlier believed.

Another groundwater study was released in 2005 by Nassau County [22] looking at conditions for the years 2000 to 2003. Once again, applying the traditional safe yield approach, the county concluded that "since average recharge to the groundwater system (approximately $341 \mathrm{mgd}$ ) exceeds the amount of groundwater withdrawn from the system (currently in the $200 \mathrm{mgd}$ range), available groundwater resources are more than sufficient to meet present and anticipated future water demand" [22]. The report also noted that...

"average annual water demand has crept upwards due to increased groundwater withdrawal during the peak pumping months. Demand increased from an average of approximately $185 \mathrm{mgd}$ during the 1990's, to an average of approximately 193 over the last five years, primarily due to lawn watering during the warmer months. Additionally, annual demand over three of the last five years has equaled or exceeded $200 \mathrm{mgd}$."

Although Nassau County is exceeding its own safe yield value, the county considers the water conditions to be acceptable. Regardless of its assurances, however, the 2005 report shows that total water loss from the aquifer system 
(pumpage plus natural outflow) was documented at $404 \mathrm{mgd}$ which is notably more than the $341 \mathrm{mgd}$ in recharge coming into the aquifer system.

It is likely that in Nassau County, natural outflow from the aquifer system will decline further. More water will be lost from storage, outflow to the oceans will decline, stream flow will drop, and there will be an increased risk of saltwater contamination for portions of the aquifers. Undesirable impacts will almost certainly increase.

\section{Developing a new approach to aquifer management: managed yield}

First, comparing recharge to withdrawal in order to define "safe yield" is a discredited approach for determining how much is too much water to take out of an aquifer system.

Second, safe yield or sustainable yield, is not a specific number or amount of water that an aquifer can reliably provide. As conditions change, the amount of water an aquifer system can properly provide will change.

Third, a community must clearly identify the unacceptable consequences it is unwilling to accept when considering the yield or the amount of water the community can capture from an aquifer system. This should follow the six-step process outlined by Sophocleous and others.

Fourth, there are a number of uncertainties that must be recognized and factored into the process. The most recent is climate change and related to it, sea level rise, precipitation changes and the frequency of hot or dry spells.

Finally, many regulatory frameworks use a safety margin or factor when dealing with critical consequences and decisions. A safety factor is built into some regulations, for example, drinking water standards. In economic and budgeting procedures, a reserve fund is established. It may be called a rainy day account or reserve savings account that provides a budgetary backup if the worst case scenario arises.

When determining how much water can be drained from a surface water reservoir, planners rarely consider it prudent to drain the reservoir dry. There is always a level of drawdown below which planners and system operators do not want to exceed. Groundwater systems should be no different. The goal should not be to see how close water production can come to the recharge rate in deciding if water loss from the system is too much. It is possible with a groundwater system that long before the withdrawals approach total recharge that changes to the system could be dire, especially where a system is surrounded by sea water. Lowering the water table below sea level could be catastrophic even if a large amount of water remains in storage. Similarly, reducing outflow to the coastal margins will facilitate saltwater intrusion, again a damaging and undesirable impact to the system.

For groundwater systems, especially those at risk in places such as islands, or where long-term forecasts indicate less precipitation or recharge over time, the use of a safety margin would be very valuable. The approach would be to conduct the full water budget analysis, accounting for all three parameters: 
inflow, outflow and change in storage. Then, with the full participation of the affected community, the undesirable consequences should be identified. Finally, there should be a set aside of a certain percentage of production potential that the community agrees it will not develop, thus providing a cushion of extra water for unexpected conditions or emergencies. A set aside of anywhere from 10 to $40 \%$ seems reasonable. The safety margin would depend on many considerations, such as how much water the set aside actually represented, how much of an impact this would have on the community at the present or the future, how soon the community would hit its threshold limit, and could the community still grow and prosper using creative ways to conserve its water supply?

This approach would be a managed yield from the aquifer system. This does not imply a value judgment as to safe or unsafe. It also implies that the yield is a dynamic value that will respond as conditions warrant.

Managed yield could be defined as the amount of water a community identifies as available from an aquifer system, including a safety margin so that aquifer changes do no reach the point where undesirable consequences can occur. This definition refines the 6-step process outlined by Mandel and Shiftan [18], using step \#2 (identify the most stringent constraint on the system) as the threshold where the safety margin is assessed.

Through the application of managed yield, communities can have a greater impact on how the aquifer system changes with time and provide long-term management of their water supply.

In the final analysis, “...the solution to regional and local water problems requires education, technical assistance, and supporting research. It is imperative that the community at large participates in policy formulations and in judgments of what is to be sustained. Strong public education and outreach programs are needed to improve understanding of the nature, complexity, and diversity of groundwater resources, and to emphasize how this understanding must form the basis for operating conditions and constraints. This is the only way to positively influence, for the long term, the attitudes of the various stakeholders involved. Pressure from the community for better management of our natural resources will be the main driving force for most changes" [12]. This summarizes the challenge and goal for managed yield perfectly.

\section{References}

[1] "Water, Our Thirsty World." National Geographic Magazine, Special Issue. April 2010.

[2] Marshall, Jessica. "Groundwater Levels Draining Fast." Discovery News. September 27, 2010. http://news.discovery.com/earth/groundwater-aquiferagriculture.html (accessed December 3, 2010).

[3] Wada, Y., L.P.H. van Beek, J.W. Reckman, S. Vasak, and M.F. Kierkens. "Global depletion of groundwater resources." Geophysical Research Letter, October 2010.

[4] Soos, Andy. "Disappearing Ground Water." ENN: Environmental News Network. September 27, 2010. http://enn.com/pollution/article/41821 (accessed December 2, 2010). 
[5] Belford, Aubrey. "Too Little, Then Too Much in Australia." The New York Times, January 16, 2011.

[6] Bartolino, J.R., and W.I. Cunningham. Ground-Water Depletion Across the Nation. Fact Sheet 103-03, Reston: U.S. Geological Survey, 2003.

[7] Alley, William M., Thomas Reilly, and O. L. Franke. Sustainability of Ground-Water Resources. USGS Circular 1186, Denver: USGS, 1999, 79.

[8] Bredehoeft, J.D., S.S. Papadopulos, and H.H. Cooper. "Groundwater: The Water Budget Myth.” In Scientific Basis of Water Resource Management, 51-57. Washington, DC: National Academy Press, 1982.

[9] Bredehoeft, J.D. “The Water Budget Myth Revisited: Why Hydrogeologists Model.” GROUNDWATER 40, no. 4 (July-August 2002): 340-345.

[10] Loaiciga, H.A. "Comments on "The persistence of the water budget muth and its relationship to sustainability" by J.F. Devlin and M. Sophocleous, Hydrology Jounal (2005) 13:549-554.” Hydrology Journal 14 (2006): 1383-1385.

[11] Sophocleous, Marios. Bulletin 239: Perspective on Sustainable Development of Water Resources in Kansas. Bulletin 239, Kansas Geological Survey, Lawrence: University of Kansas, 1998, 61-85.

[12] Sophocleous, M. "From safe yield to sustainable development of water resources - the Kansas experience." Journal of Hydrology 235 (2000): 2743.

[13] Alley, William M., and S.A. Leake. "The Journey from Safe Yield to Sustainability." GROUNDWATER 42, no. No. 1 (Jan-Feb 2004): 12-16.

[14] Lee, C.H. "The determination of safe yield of underground reservoirs of the close basin type." Transactions, American Society of Civil Engineers 78, 1915: 148-251.

[15] Todd, K.D. Ground Water Hydrology. New York: John Wiley, 1959.

[16] Freeze, R.A.: Cherry, J.A. Groundwater. Englewood Cliffs, New Jersey: Prentice-Hall, 1979.

[17] American Society of Civil Engineers Task Committee for Sustainability Criteria. Sustainability criteria for water resource systems. ASCE, 1998.

[18] Mandel, S, and Z.L. Shiftan. Ground-water Resources - Invesigation and development. New York, New York: Academic Press, 1981.

[19] Nassau County, New York. Nassau County 1998 Groundwater Study. Nassau County Department of Public Works, 1998.

[20] Maimone, Mark. "Defining and Managing Sustainable Yield." GROUNDWATER 42, no. No. 6 (November-December 2004).

[21] St. Germain, D.J., D.K. Cohen, and J.J. Frederick. "A Retrospective Look at the Water Resource Management Policies in Nassau County, Long Island, New York." Journal of the American Water Resources Association 44, no. No. 5 (October 2008): 1337-1346.

[22] Nassau County Department of Public Works. Groundwater Monitoring Program: 2000-2003. Mineola: Nassau County, NY Department of Public Works, 2005, 125. 